\title{
Penggunaan Lagu dan Dongeng Bahasa Inggris untuk Meningkatkan Kesadaran tentang Polusi Udara bagi Peserta TBM Kolong Jalan Layang Ciputat
}

\author{
Lisa Suhayati \\ Universitas Pamulang \\ dosen00604@unpam.ac.id
}

\begin{abstract}
The Community Service Activity is aimed to carry out one of the Tri Dharma of Higher Education. Additionally, by doing community services, the existence of higher education institutions can contribute to the development and application of knowledge to the community. Therefore, a team from English Literature Study Program of Universitas Pamulang initiated to conduct a community service to children in TBM Kolong Jembatan Ciputat, an organization that focuses on education and community development in Ciputat, Tangerang Selatan, Banten. Based on the fact of the height of air pollution in Ciputat, the team intended to deliver information related air pollution through Emglish songs and storytelling to raise their awareness on this issue. Based on the observation, it is found that the children gave positive attitude toward the use of English songs and storytelling to raise their awareness on air pollution. Besides, they enrich the English vocabularies through the story told by the tutors.
\end{abstract}

Keywords: air pollution, community service, english, storytelling

\begin{abstract}
Abstrak
Kegiatan Pengabdian kepada Masyarakat (PKM) bertujuan untuk mengimplementasikan salah satu dari Tri Dharma Penguruan Tinggi. Lebih jauh lagi, dengan melakukan kegiatan Pengabdian kepada Masyarakat ini, kehadiran institusi perguruan tinggi dapat memberikan kontribusi yang bermanfaat terhadap perkembangan dan pengaplikasian ilmu pengetahuian. Oleh karena itu, salah satu tim Pengabdian kepada Masyarakat dari program studi Sastra Inggris Universitas Pamulang bermaksud untuk melakukan pengabdian kepada masyarakat kepada anak-anak di Taman Bacaan Masyarakat Kolong Jembatan Ciputat, yaitu sebuah organisasi yang kegiatannya memberikan perhatian terhadap pendidikan dan pengembangan masyarakat di wilayah Ciputat Tangerang Selatan, Banten. Berdasarkan fakta bahwa betapa tingginya polusi udara di wilayah Ciputat, tim bermaksud untuk melakukan penyuluhan terkait polusi udara melalui lagu dan dongeng. Dari hasil obeservasi, diperoleh bahwa anak-anak memberikan reaksi yang positif terhadap penggunaan lagu dan dongeng untuk meningkatkan kesadaran mereka terkait polusi udara. Selain itu, mereka juga memperkaya kosa kata Bahasa Inggris mereka melalui cerita yang dibawakan oleh para tutor.
\end{abstract}

Kata kunci: English, Dongeng, Pengabdian kepada Masyarakat, Polusi Udara 


\section{A. Pendahuluan}

Tingginya tingkat polusi udara di kota-kota besar termasuk daerah di pinggiran kota Jakarta tidak bisa dipungkiri sudah sejak lama meresahkan banyak pihak, terutama masyarakat yang tinggal di kota tersebut. Ciputat adalah sebuah kecamatan di Tangerang Selatan, Banten yang berada tidak jauh dari ibu kota. Meski terhitung sebagai sebuah kecamatan, namun tingkat mobilitas penduduknya luar biasa tinggi. Oleh karena itu, polusi yang disebabkan oleh asap kendaraan bermotor tidak dapat dihindari. Hal ini merupakan sebuah keniscayaan karena kendaraan bermotor dibutuhkan oleh masyarakat sebagai sarana transportasi, baik umum maupun pribadi. Selain disebabkan oleh asap kendaraan bermotor, polusi udara di daerah Ciputat disebabkan pula oleh masih adanya proses pembakaran sampah rumah tangga oleh beberapa warga masyarakat.

Seperti yang tertulis di https://kanalkomunikasi.pskl.menlhk.go.id di kelurahan serua indah kecamatan ciputat, warga rt 01/006 masih melakukan pengelolaan sampah dengan cara membakar sampah yang dilakukan di dalam pemukiman sehingga mengganggu kenyamanan warga dan menyebabkan polusi udara aklibat asap sebagai hasil dari pembakaran sampah. Mereka seakan tidak menyadari bahwa asap tersebut dapat membahayakan kesehatan mereka juga warga sekitar.

Tidak hanya karena proses pembakaran sampah, polusi udara juga dihasilkan dari sampah-sampah yang dengan sembarangan dibuang warga ke beberapa ruas jalan. Seringkali ditemukan kantong plastic berisi sampah-sampah rumah tangga yang sebagian besar sudah busuk dan berbau menyengat. Tak ayal, Ciputat sempat dijuluki sebagai "Kota Sampah" oleh masyarakat sekitar. (artikel kompasiana).

Polusi udara memiliki dampak yang amat buruk bagi manusia. S.A. Indyah (2005) mengatakan bahwa kesehatan pada manusia akan terganggu akibat udara yang tercemar yang bisa mengakibatkan timbulnya penyakit seperti infeksi saluran pernapasan, paru-paru, jantung dan juga sebagai pemicu terjadinya kanker yang sangat berbahaya. Selanjutnya efek yang ditimbulkan pada lingkungan ekosistem adalah kerusakan dimana lingkungan ekosistem tempat tinggal berbagai macam makhluk hidup seperti akibat kebakaran hutan merusak tumbuh-tumbuhan dan hewan. Sedangkan hujan asam disebabkan oleh belerang (sulfur) yang merupakan polutan dalam bahan bakar fosil serta nitrogen di udara yang bereaksi dengan oksigen membentuk sulfur dioksida dan nitrogen dioksida. Polutan tersebut berasal dari knalpot mobil dan industri yang menggunakan bahan bakar minyak dan batubara. Di atmosfir, polutan tersebut membentuk asam sulfat (H2SO4) dan asam nitrat (HNO3). Akhirnya mereka jatuh ke tanah sebagai hujan asam. Hal ini tentu saja sangat berbahaya dan mengancam keselamatan manusia yang tinggal di daerah yang polusi udaranya tinggi.

Safitri (2019), seorang pegiat kesehatan masyarakat dalam laman honest.doc mengujarkan fakta bahwa bayi dan anak-anak berisiko $60 \%$ lebih besar terkena paparan polusi daripada orang dewasa. Hal ini dikarenakan paruparu bayi dan anak belum cukup sempurna dan masih dalam tahap perkembangan, sehingga polutan cenderung lebih mudah terhirup dan masuk ke saluran pernapasannya.Hal ini tentu saja tidak dapat diabaikan begitu saja. Safitri (2019) 
melanjutkan keterangannya bahwa udara yang tercemar merupakan racun bagi jutaan bayi dan anak-anak di seluruh dunia. Sistem imun tubuh bayi dan anakanak yang rentan membuat kedua golongan ini lebih mudah terkena penyakit, khususnya yang berasal dari paparan polusi udara. Terlebih lagi, anakanak senang menghabiskan lebih banyak waktu di luar ruangan untuk bermain, berolahraga, dan beraktivitas. Mereka akhirnya menghirup udara lebih banyak sehingga risiko terpapar polusi pun juga semakin tinggi.

Masalah ini, tentu saja harus segera ditangani, tidak hanya oleh pemerintah tapi juga masyarakat secara menyeluruh. Pemerintah bukan tidak mungkin melakukan berbagai alternatif untuk menangani masalah ini. Akan tetapi, bila semua usaha dan kebijakan pemerintah tidak diiringi dengan kesadaran masyarakat akan pentingnya menjaga tempat tinggal mereka dari polusi udara, maka semua usaha bukan tidak mungkin akan sia-sia adanya. Untuk itu, diperlukan adanya kesadaran masyrakat tentang lingkungannya sendiri.Tentu saja, kesadaran masyarakat akan pentingnya menjaga lingkungan sekitar haruslah dipupuk sejak dini, saat mereka masih kanak-kanak agar bisa berefek jangka panjang. Hal ini merupakan tanggung jawab bersama. Sinergi dari seluruh sumber daya yang ada di lingkungan itu sendiri haruslah menggalakannya.

Para relawan TBM (Taman Bacaan Masyarakat) Kolong Jembatan Ciputat, adalah salah satu dari segelintir pihak yang peduli atas permasalahan ini. Tidak hanya terkait dengan masalah polusi, tapi juga masalah social lainnya. TBM Kolong Jembatan Ciputat adalah sebuah taman baca yang diprakarsai oleh Komunitas OI Tangsel dan FISIP UIN Syarif Hidayatullaah Mengajar. Merekalah yang menyulap tempat tersebut menjadi Taman Baca Masyarakat (TBM) Kolong pada 2016. Sebelumnya, tempat ini adalah pos petugas Satpol PP yang sering digunakan oleh para sopir angkot untuk beristirahat. Devina Febrianti, salah satu pengelola TBM Kolong mengatakan bahwa tindakan asusila, kekerasan, tempat singgah anak pank. Jadi banyak yang beranggapan negatif ketika ruang ini belum dimaksimalkan. Tetapi saat ini, TBM Kolong Jembatan Ciputat telah menjadi salah satu wadah bagi warga, terutama anak-anak yang memberi begitu banyak manfaat untuk mereka denganberagam kegiatannya. Selain membaca, kegiatan yang ada disini ialah dongeng, bimbingan belajar, kreasi dan seni. Semua kegiatan ini tidak berbayar dan diisi oleh para relawan dari berbagai tempat.

Penulis menganggap bahwa TBM Kolong Ciputat adalah wadah yang tepat bagi tim Pengabdian kepada Masyarakat untuk berbagi informasi tentang betapa pentingnya menjaga lingkungan sekitar dari polusi, khususnya polusi udara kepada masyarakat, terutama anak-anak yang diharapkan bisa menjadi agen perubahan karena waktu mereka masih sangat Panjang. Adapun usaha untuk meningkatkan kesadaran masyarakat, terutama anak-anak terhadap suatu masalah yang ada di tengeah lingkungan mereka tidaklah mudah. Oleh karena itu, diperlukan media dan teknik yang tepat agar pesan yang disampaikan kepada mereka dapat diterima dengan baik dan bisa diaplikasikan dalam kehidupan mereka.

Nana Sudana dan Ahmad Rivai (2011), media pembelajaran dapat diklasifikasikan menjadi beberapa klasifikasi yaitu:

1. Dilihat dari sifatnya, media dibagi ke dalam: 
a) Media auditif, yaitu media yang hanya di dengar saja.

b) Media visual, yaitu media yang hanya dilihat saja.

c) Media audiovisual, yaitu jenis media yang selain mengandung unsur suara juga mengandung unsur gambar yang bisa dilihat.

2. Dilihat dari kemampuan jangkauannya media dapat di bagi ke dalam:

a) Media yang memiliki daya liput yang luas dan serentak seperti radio dan televisi.

b) Media yang mempunyai daya liput yang terbatas oleh ruang dan waktu seperti film slide, film, video.

3. Dilihat dari cara atau teknik pemakaiannya, media dibagi ke dalam:

a) Media yang di proyeksikan seperti film, slide, film strip, transparansi.

b) Media yang tidak diproyeksikan seperti gambar, foto, lukisan, radio.

Pada kegiatan Pengabdian kepada Masyarakat (PkM) kali ini, tim menggunakan teknik English songs and storytelling (lagu dan dongeng Bahasa Inggris) sebagai media dalam aktifitas belajar bersama anak-anak didik TBM Kolong sebagai usaha untuk meningkatkan kesadaran mereka mengenai polusi udara. Penulis berharap bahwa dengan penggunaan media ini, tujuan pembelajaran yakni munculnya kesadaran para peserta didik akanberbahayanya polusi udara bagi mereka. Terkait hal ini, Hamalik (2006, p. 30) mengatakan bahwa hasil belajar adalah bila seseorang telah belajar akan terjadi perubahan tingkah laku pada orang tersebut. Oleh karena itu, melalui kegiatan pembelajaran ini kesadaran para peserta didik akan pentingn ya menjaga lingkungan dari polusi udara dapat tumbuh dan semakin meningkat. Di samping itu, ke depannya mereka dapat membagi apa yang sudah mereka fahami ke masyrakat lain di lingkungannya, contohnya kepada teman sebaya, orangtua dan orang lain di sekitarnya, sehingga tidak hanya berefek ke diri mereka sendiri saja.

Hal ini sejalan dengan apa yang dikatakan Nasution (1990, p. 21) bahwa hasil belajar adalah hasil pembelajaran dari suatu individu tersebut berinteraksi secara aktif dan positif dengan lingkungannya.Di TBM Kolong Ciputat, para peserta didik menyaksikan sendiri bahwa polusi udara di sekitar mereka nyata adanya. Ini dibuktikan dengan betapa padatnya arus kendaraan bermotor di sekitar tempat mereka beraktifitas. Mereka bisa merasakan sendiri, sehingga ke depannya mereka bisa menjadi agen perubahan untuk perbaikan di lingkungan sekitar mereka.Kegiatan ini menggunakan beberapa media belajar, yaitu lagu, wayang kertas (paper puppet) dan flanel gulung yang berisi cerita dalam gambar. Gerlach dan Ely dalam Arsyad mengatakan bahwa media apabila dipahami secara garis besar adalah manusia, materi, atau kejadian yang membangun kondisi yang membuat siswa mampu memperoleh pengetahuan, keterampilan, atau sikap (Azhar, 1997). Oleh karena itu penulis menggunakan media yang telah disebutkan tadi agar peserta didik dapat mengikuti kegiatan dengan gembira dan memahami pengetahuan yang disampaikan dengan baik.

Berikut adalah keuntungan-keuntungan yang bisa diperoleh dari penggunaan lagu dan dan dongeng (storytelling):

1. Lagu- lagu (songs)

Lagu dipilih sebagai salah satu media dalam kegiatan ini karena lagu dapat mempengaruhi mood anak. Apabila temanya ceria, lagu dapat mejadi 
penyemangat anak untuk belajar. Tidak dipungkiri bahwa lagu juga dapat meningkatkan kosakata anak. Mereka juga turut serta andil dalam kegiatan pelajaran dengan bernyanyi bersama. Hal ini sejalan dengan apa yang disampaikan Agus Suprijono (2012, p. 10) bahwa diharapkan pesan yang disampaikan juga dapat meresap ke sanubari mereka. Pembelajaran di dalam kelas harus menumbuhkan suasana yang baik sehingga siswa aktif bertanya, mempertanyakan, dan mengemukakan gagasan.

\section{Dongeng (storytelling)}

Latif A (2012, p. 51) mengemukakan bahwa bercerita adalah metode yang sangat baik dalam pendidikan. Pada umumnya, cerita disukai oleh jiwa manusia karena memiliki pengaruh yang menakjubkan untuk dapat menarik perhatian pendengar dan membuat seseorang bisa mengingat kejadiankejadian dalam sebuah kisah dengan cepat. Storytelling memberikan pengalaman bagi anak dalam proses pembelajarannya. kegiatan storytelling mendukung pemahaman anak dan sangat penting dalam perkembangan bahasa anak. Selain itu juga dengan kegiatan storytelling membantu siswa memahami berbagai perbedaan multikultural dan pembelajaran kelompok. Selanjutnya, Nur Azizah \& Ali, (2017) mengatakan bahwa metode Storytelling dilakukan dengan enam cara yaitu: (1) membaca langsung dari buku cerita; (2) menggunakan ilustrasi dari buku; (3) Mendongeng; (4) Menggunakan papan flanel; (5) menggunakan boneka; dan (6) memainkan jari-jari tangan. Lebih jauh lagi, Cakra dalam Nur Azizah \& Ali (2017, p. 5) menjelaskan bahwa kriteria memilih cerita atau dongeng terdiri atas: (1) mengandung unsur-unsur alami pendidikan dan agama; (2) mengandung nasehat dan contoh suri tauladan dan akhlak yang mulia; (3) cerita tidak merusak kepribadian anak; (4) berikan suasana yang menarik ketika menyampaikan dongeng (gembira, sedih atau marah dan sebagainya). Fitroh et al., (2015) juga menjelaskan bahwa cerita rakyat merupakan sarana pembelajaran budaya yang baik bagi anak karena mengangdung ciri khas, dan kultur budaya yang beraneka ragam dan mencakup kekayaan budaya dan sejarah yang dimiliki masing-masing daerah di indonesia. Mereka juga mengatakan bahwa dongeng sebagai media dalam penanaman karakter sangatlah efektif untuk diterapkan kepada anak usia dini dan perlunya pembiasaan serta contoh yang baik untuk menumbuhkan karakter dari anak. Mendongeng adalah cara yang efektif untuk menyampaikan pesan dan nilainilai moral bagi anak-anak dengan cara yang menyenangkan. Tentu saja belajar dengan cara yang menyenangkan akan menambah motivasi para siswa untuk dating ke tempat belajar. Adhi (2014, p. 1) menambahkan bahwa mendongeng adalah model pendidikan karakter yang dapat dikembangkan dalam proses pembelajaran di sekolah atau di keluarga, karena substansi dongeng atau cerita mengandung banyak nilai moral (kearifan lokal) yang bernilai. Oleh karena itu dongeng (storytelling) memiliki banyak manfaat apabila digunakan dalam kegiatan pembelajaran dengan baik dan sesuai. 


\section{B. Pelaksanaan dan Metode}

Kegiatan Pengabdian kepada Masyarakat ini dilaksanakan pada tanggal 68 Desember 2019 di Taman Bacaan Masyarakat (TBM) Kolong Jembatan Ciputat, Tangerang Selatan, Banten. Taman bacaan ini berada tepat di seberang Pasar Ciputat yang sangat ramai dan padat. Tidak hanya itu, lokasi ini berada tepat di bawah jembatan layang dan di tengah dua jalan besar yang satu sisinya mengarah ke Lebak Bulus, Jakarta Selatan dan sisi lainnya mengarah ke Pamulang atau Parung. Meskipun terletak di lokasi yang mungkin terlihat tidak begitu nyaman, faktanya, berdasarkan pantauan kami selama observasi lapangan, banyak peserta didik yang datang secara rutin untuk mengikuti kegiatan-kegiatan yang ada di tempat ini.

Peserta didik di TBM Kolong terdiri dari berbagai usia, mulai dari balita hingga siswa yang sudah duduk di bangku SMA. Rata-rata dari mereka tinggal tidak jauh dari lokasi TBM berada, sehingga banyak dari mereka yang hanya berjalan kaki dari rumah mereka sampai ke lokasi belajar. Sebagian dari peserta didik adalah anak dari para pedagang di paar Ciputat, ada juga yang merupakan anak penjaja makanan disana, juga anak dari sopir angkot yang tinggal di sekitar lokasi. Akan tetapi, beberapa dari mereka juga merupakan anak dari para orang tua yang latar belakang social dan ekonominya lebih mapan. Mereka mengajak anak mereka untuk berkegiatan disana karena TBM Kolong memfasilitasi beragam kegiatan, seperti bimbingan belajar dan seni keterampilan.

Adapun metode yang digunakan dalam dalam Pengabdian kepada Masyarakat ini berupa penyampaian materi secara verbal mengenai bahaya polusi udara bagi masyrakat yang diharapkan dapat meningkatkan kesadaran mereka akan hal ini dan kemudian dapat menjadi contoh bagi orang di sekitarnya, terutama teman-teman sebaya mereka. Dalam kegiatan ini, dongeng (storytelling) dengan wayang kertas dan lagu (songs) digunakan untuk menyampaikan materi pembelajaran yang bagi para peserta didik. Kedua media ini digunakan untuk menarik minat para peserta didik sehingga mereka bisa menjalani kegiatan ini dengan menyenangkan. Adapun prosedur dari kegiatan ini adalah:

1. Membagi tim dan peserta didik menjadi tiga (3) kelompok berbeda sesuai dengan level usia mereka, yaitu usia PAUD, usia SD, dan usia SMP.

2. Mengenalkan cerita

3. Membacakan cerita dengan bantuan media berupa pertunjukan wayang kertas yang berisi sumber-sumber polusi udara dan buku flannel gulung tentang cerita rakyat yang dikaitkan dengan pokok bahasan.

4. Meminta mereka mengulang cerita melalui metode "recall" dengan bertanya kepada mereka menggunakan pertanyaan $5 \mathrm{~W} 1 \mathrm{H}$ mengenai tokoh dan isi cerita.

5. Mendiskusikan kosakata yang ada di dalam cerita.

6. Mendiskusikan pesan yang bisa diambil dari cerita yang dibacakan.

7. Menyanyikan lagu yang berhubungan dengan cerita.

8. Memberikan kesempatan kepada anak-anak untuk bermain dengan media yang ada dan bertanya. 


\section{Hasil dan Pembahasan}

\section{Evaluasi Pelaksanaan Kegiatan Belajar melalui Dongeng dan Lagu}

Secara umum, para peserta didik di TBM Kolong Jembatan Ciputat menunjukan antusiasme yang tinggi terhadap kegiatan ini. Ketika kami pertama kali menunjukan buku flannel gulung yang warnanya sangat menarik dan berisi kehidupan biota air dan pemandangan alam yang indah, mereka terlihat sangat takjub. Setelah ditanya apakah mereka pernah melihat buku seperti ini sebelumnya, mereka kompak menjawab tidak pernah. Jadi, itu adalah pertama kalinya mereka melihat buku dengan bentuk seperti itu. Selama ini mereka hanya tau dan melihat buku bergambar yang terbuat dari kertas.

Untuk masing-masing kelompok usia, kegiatan diawali dengan memperkenalkan sumber-sumber polusi udara yang dicontohkan dengan menggunakan panggung kecil yang terbuat dari kardus bekas yang dihias sedemikian rupa dan wayang kertas ukuran kecil yang dibentuk menjadi tokohtokoh dalam cerita beserta unsur-unsur pendukungnya. Sumber-sumber polusi udara itu sendiri terdiri dari kebakaran hutan, asap kendaraan bermotor dan pembakaran sampah rumah tangga di sekitar rumah warga. Semua ini dibuat menggunakan wayang kertas hasil karya mahasiswa program studi sastra Inggris Universitas Pamulang. Wayang ini dibuat untuk menggambarkan situasi dan kondisi yang sedang kita sampaikan.

\section{a. Kelompok Usia PAUD}

Ketika para peserta sudah dibagi menjadi kelompok umur, dimulailah kegiatan bercerita dengan diawali pengenalan sumber-sumber polusi udara. Terlihat bahwa para peserta didik merasa tertarik saat cerita sudah dimulai. Peserta didik usia PAUD terlihat paling antusias dengan panggung kecil yang dibuat itu. Mereka sangat ingin memegang langsung wayang kertas yang sedang dipakai untuk memeragakan cerita, sehingga para tutor sesekali memperbolehkan mereka memegangnya.

Sama halnya ketika cerita dalam buku flannel gulung disajikan, hampir semua peserta menghampiri para tutor untuk memegang buku dan membuka gulungan yang harusnya dibuka satu per satu. Akan tetapi hal ini dapat diatasi oleh para tutor. Adapun isi dari buku flannel gulung adalah cerita rakyat yang dihubungkan dengan pokok bahasan kegiatan. Meski mungkin mereka belum bisa memahami ceritanya secara utuh seperti kaka-kaka mereka yang berada di kelompok usia di atasnya, setidaknya mereka dapat memperkaya kosakata mereka terkait permasalahan yang ada.

b. Kelompok Usia SD - SMP

Di kelompok usia yang lebih besar, yaitu SD- SMP, mereka sudah lebih bisa merespon dengan lebih kritis. Saat ada adegan seorang ibu sedang membakar sampah di depan rumahnya, salah satu di antara mereka yang berkata "ibuku sering nih bakar sampah di belakang rumah" dan diikuti oleh beberapa di antara mereka yang berkata "iya ibuku juga". Bahkan salah satu dari mereka berkata bahwa mereka sendiri pernah melakukannya. 
Kemudian para tutor melanjutkan cerita dan disertai dengan pesan bahwa membakar sampah di sekitar rumah dapat menimbulkan beberapa masalah kesehatan bagi warga sekitar. Para peserta terlihat memahami respon dari para tutor dengan menganggukkan kepala mereka. Mereka juga mampu menyimpulkan bahwa ketika naik sepeda motor, seharusnya mereka menggunakan masker seperti contoh tokoh yang ada di atas panggung.

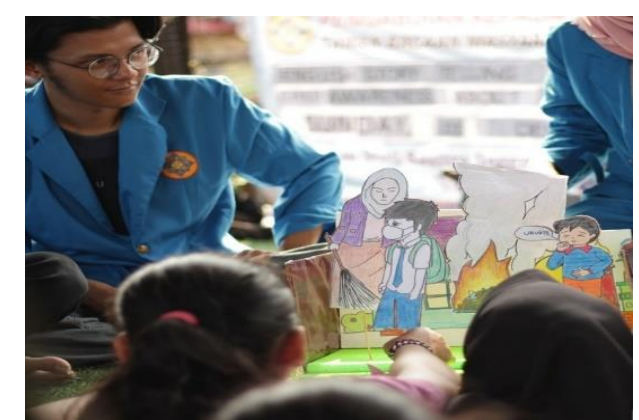

Gambar 1. Penggunaan Wayang Kertas dalam Kegiatan

Di kelompok usia ini juga disajikan cerita rakyat melalui buku flannel gulung. Di dalam cerita terdapat pemandangan yang indah dan udara yang terlihat sangat bersih tanpa asap kendaraan bermotor maupun pembakaran sampah, sehingga ini bisa jadi gambaran bahwa seharusnya seperti inilah udara yang mereka hirup.

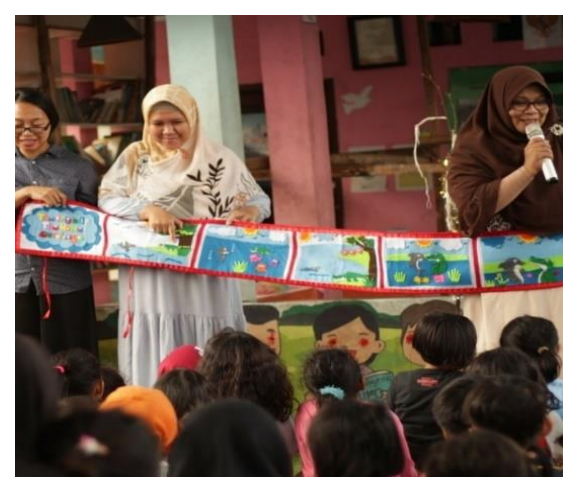

Gambar 2. Penggunaan Buku Flanel Gulung

\section{Pemerolehan Bahasa Inggris anak}

Manfaat yang dapat diperoleh dari penguasaan Bahasa Inggris tentu saja akan berdampak positif bagi peserta didik. Hal ini akan membantu mereka dalam memperoleh ilmu pengetahuan baik di bidang akademik maupun non akademik. Di tengah perkembangan dunia yang sangat pesat ini, penguasaan Bahasa Inggris akan sangat membantu mereka dalam menghadapi kompetisi global. Hal ini juga akan menolong mereka dalam penguasaan teknologi yang sebagian besarnya berbahasa Inggris. Akan tetapi, pemerolehan Bahasa Inggris tidaklah mudah, apalagi di negara kita yang mempelajari Bahasa Inggris sebagai bahasa Asing atau Foreign Language. Anak-anak tidak memiliki banyak kesempatan untuk mendapat 
paparan teks atau ujaran berbahasa Inggris. Selain itu, kesempatan untuk mempraktekkan kosa kata atau tata bahasa yang mereka sudah peroleh di sekolah pun masih rendah. Ini terjadi karena banyak orangtua peserta didik, juga orangorang di lingkungan sekitar mereka tidak bias berbahasa Inggris, sehingga sulit bagi mereka untuk bias menguasainya.

Oleh karena ini, salah satu tujuan dari kegiatan PkM ini adalah untuk menambah wawasan para peserta didik agar dapat memperkaya kosa kata mereka terutama yang terkait dengan polusi udara dan lingkungan. Berdasarkan informasi yang diperoleh dari interaksi yang dilakukan penulis dengan para peserta didik, ditemukan beberapa pemerolehan Bahasa Inggris anak. Pemerolehan Bahasa Inggris tersebut dijelaskan dengan tabel berikut ini:

Tabel 1: Pemerolehan Bahasa Inggris Peserta

\begin{tabular}{|c|c|}
\hline Kegiatan & $\begin{array}{c}\text { Contoh Pemerolehan } \\
\text { Bahasa Inggris }\end{array}$ \\
\hline $\begin{array}{l}\text { Pengenalan sumber- } \\
\text { sumber polusi udara } \\
\text { melalui wayang } \\
\text { kertas }\end{array}$ & $\begin{array}{l}>\text { Air } \\
>\text { Fire } \\
>\text { Smoke }\end{array}$ \\
\hline & $\begin{array}{l}>\text { Mask } \\
>\text { Trash } \\
>\text { Broom } \\
>\text { Dust } \\
>\text { Transportation } \\
>\text { Traffic Jam } \\
>\text { Forest } \\
>\text { Forest fire } \\
>\text { Burn } \\
>\text { Sweep } \\
>\text { Breathe }\end{array}$ \\
\hline $\begin{array}{l}\text { Pembacaan dongeng } \\
\text { melalu buku flannel } \\
\text { gulung }\end{array}$ & $\begin{array}{l}>\text { Sky } \\
>\text { Blue }\end{array}$ \\
\hline
\end{tabular}




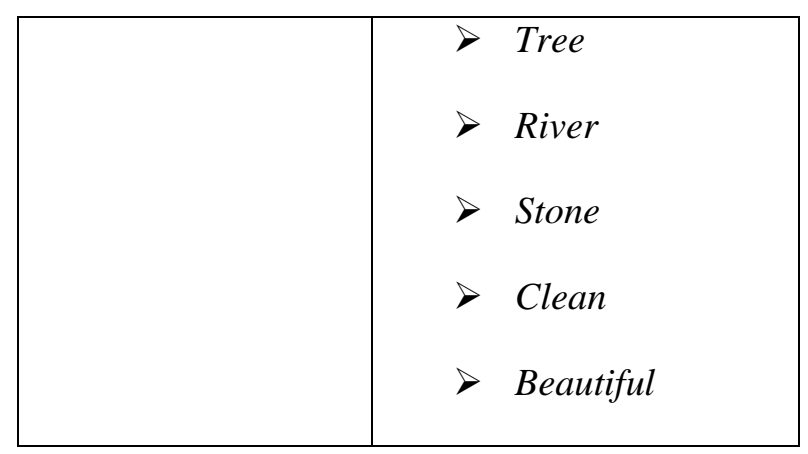

Secara umum, berdasarkan hasil pengamatan penulis pada kegiatan PkM bersama peserta didik di lapangan, ditemukan bahwa tidak semua dari mereka faham akan dampak negative dari polusi udara. Hal ini disebabkan salah satunya adalah di lingkungan rumah mereka, terutama di dalam rumah mereka, tidak pernah ada yang membahas isu ini. Bahkan, orangtua mereka sendiri tidak pernah membahas isu ini ketika mereka sedang berinteraksi bersama anggota keluarga di rumah. Mereka hanya mendapat sebagian kecil informasi saja dari guru-guru mereka di sekolah. Sebagian dari mereka juga tidak mengetahui bahwa di sejumlah wilayah di Indonesia sering terjadi kebakaran hutan yang menimbulkan kabut asap yang berbahaya bagi kesehatan. Hal lain yang penulis temukan adalah sebagian besar dari anak-anak ini tidak pernah memakai masker ketika mereka pergi menggunakan sepeda motor Bersama orangtua mereka meski melalui jalan yang penuh dengan kendaraan bermotor yang menghasilkan polusi udara. Terlebih lagi, orangtua mereka pun tidak memakainya.

Oleh karena itu, penulis mengganggap bahwa membangkitkan kesadaran anak-anak akan bahayanya polusi udara ini tidak hanya cukup dilakukan dalam satu waktu. Sosialisai dengan dengan cara yang menyenangkan seperti ini haruslah dilakukan secara berkala.

Selain itu, kesadaran dari anak-anak saja tidaklah cukup, ini perlu didukung oleh para orangtua di rumah juga masyarakat di lingkungan sekitar anak. Bukan tidak mungkin, informasi yang sudah anak-anak dapat dalam kegiatan ini tidak bisa diaplikasikan oleh mereka karena kurangnya dukungan dari seluruh pihak yang terkait.

\section{Penutup \\ Simpulan}

Berdasarkan hasil Analisa, penulis menemukan fakta bahwa para peserta didik di TBM Kolong Ciputat menunjukan antusiasme yang sangat tinggi ketika mengikuti penyuluhan ini. Hal ini terbukti dari raut wajah mereka yang senang dan gembira ketika sumber-sumber polusi udara diperkenalkan melalui panggung kecil yang diisi dengan wayang kertas.Begitupun ketika buku flannel gulung dipakai untuk mendongeng, mereka terlihat takjub karena bekum pernah melihat buku dengan bentuk seperti itu sebelumnya. Bahkan, anak-anak ikut juga memegang dan memainkan media tersebut. Saat sesi bernyanyi bersama dengan lagu yang bertema lingkunganpun, mereka dengan gembira ikut bernyanyi dan menari bersama. 
Penyuluhan ini juga memberi dampak positif bagi peserta didik, di antaranya adalah mereka mendapatkan beberapa informasi tentang sumbersumber polusi udara dan bagaimana menghindarinya yang sebelumnya mungkin tidak mereka ketahui. Selain itu, melalui cerita yang disampaikan, anak-anak juga memperoleh beberapa kosakata Bahasa Inggris yang mereka belum tahu sebelumnya, sehingga ini bias memperkaya kosakata Bahasa Inggris mereka.

\section{Saran}

Meskipun anak-anak sudah mendapatkan mengenai bahaya polusi udara, kesadaran dari mereka saja tidaklah cukup, ini perlu didukung oleh para orangtua di rumah juga masyarakat di lingkungan sekitar anak. Bukan tidak mungkin, informasi yang sudah anak-anak dapat dalam kegiatan ini tidak bias diaplikasikan oleh mereka karena kurangnya dukungan dari seluruh pihak yang terkait. Lebih jauh, penulis berharap para peserta didik mampu menggunakan kosakata itu dalam percakapan sehari-hari bersama teman-teman atau guru mereka di sekolah.

\section{Ucapan Terima Kasih}

Penulis berterimakasih kepada Bapak Markus Hino Yudhistira, Ibu Sari Fitria, Ibu Ria Antika dan Ibu Tutut Sumartini, para dosen yang telah memberikan kontribusi yang luar biasa dalam kegiatan ini. Tidak lupa penulis sampaikan terimakasih yang mendalam atas dukungan dari pimpinan program studi Sastra Inggris Ibu Tryana dan Ibu Setiana Sri Wahyuni Sitepu atas kegiatan ini. Kegiatan ini juga bisa berjalan dengan baik karena para mahasiswa/i yang dengan sangat kreatif dan tak kenal lelah membuat media pembelajaran dan menjadi tutor selama kegiatan sehingga anak-anak di TBM Kolong bisa mengikuti kegiatan dengan riang gembira.

\section{DAFTAR PUSTAKA}

Adhi, M. K. (2014). Model pendidikan karakter berbasis mendongeng. Jurnal Santiaji Pendidikan, 4(1).

Arsyad, A. (1997). Media pengajaran. Jakarta: Raja Grafindo Persada.

Arty, I. S. (2005). Pendidikan lingkungan hidup tentang bahaya polutan udara. Cakrawala Pendidikan, 3.

Fitroh, S. F., \& Sari, N. E. D. (2015). Dongeng sebagai media penananam karakter pada anak usia dini. Jurnal PG-PAUD Trunojoyo, 2(2), 76-149.

Hamalik, O. (2006). Proses belajar mengajar. Jakarta: Bumi Aksara.

Latif, M. A. (2012). The miracle of storytelling. Jakarta: Zikrul.

Nasution, S. (1990). Berbagai pendekatan dalam proses belajar dan mengajar. Jakarta: Bina Aksara. 
ACITYA BHAKTI

http://openjournal.unpam.ac.id/index.php/ACB/issue/view/605/showToc

E-ISSN: $2775-4383$

Volume 1 Nomor 1 Februari 2021

Ramdhani, S., Yuliastri, N. A., Sari, S. D., \& Hasriah, S. (2019). Penanaman nilai-nilai karakter melalui kegiatan storytelling dengan menggunakan cerita rakyat sasak pada anak usia dini. Jurnal Obsesi : Jurnal Pendidikan Anak Usia Dini, 3(1), 153. doi:10.31004/obsesi.v3i1.108

Sudjana, N., \& Rivai, A. (2011). Media pengajaran. Bandung: Sinar Baru Algesindo.

Suprijono, A. (2012). Cooperative learning: Teori \& aplikasi PAIKEM. Yogyakarta: Pustaka Pelajar 